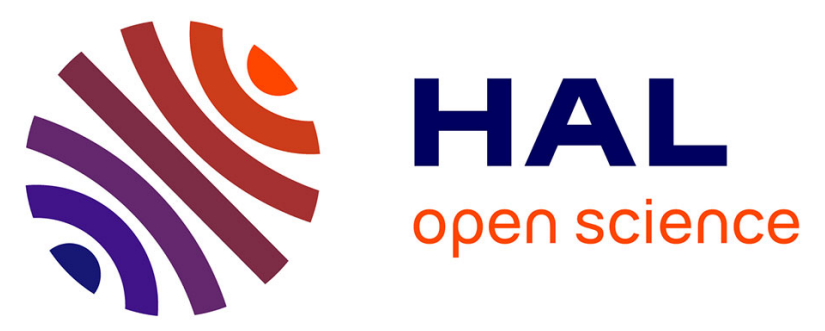

\title{
Fuel economy assessment tool for auxiliary kite propulsion of merchant ship
}

Vincent Podeur, Damien Merdrignac, Morgan Behrel, Kostia Roncin, Caroline Fonti, Christian Jochum, Yves Parlier, Philippe Renaud

\section{> To cite this version:}

Vincent Podeur, Damien Merdrignac, Morgan Behrel, Kostia Roncin, Caroline Fonti, et al.. Fuel economy assessment tool for auxiliary kite propulsion of merchant ship. La Houille Blanche - Revue internationale de l'eau, 2018, 2018 (1), pp.5-7. 10.1051/lhb/2018001 . hal-01784372

\section{HAL Id: hal-01784372 \\ https://hal-ensta-bretagne.archives-ouvertes.fr/hal-01784372}

Submitted on 27 Sep 2021

HAL is a multi-disciplinary open access archive for the deposit and dissemination of scientific research documents, whether they are published or not. The documents may come from teaching and research institutions in France or abroad, or from public or private research centers.
L'archive ouverte pluridisciplinaire HAL, est destinée au dépôt et à la diffusion de documents scientifiques de niveau recherche, publiés ou non, émanant des établissements d'enseignement et de recherche français ou étrangers, des laboratoires publics ou privés. 


\title{
Fuel economy assessment tool for auxiliary kite propulsion of merchant ship
}

\author{
Vincent PODEUR ${ }^{1}$, Damien MERDRIGNAC ${ }^{1}$, Morgan BEHREL ${ }^{1}$, Kostia RONCIN ${ }^{1}$, \\ Caroline FONTI ${ }^{3}$, Christian JOCHUM ${ }^{1}$, Yves PARLIER ${ }^{2}$, Philippe RENAUD ${ }^{3}$
}

\author{
${ }^{1}$ ENSTA Bretagne, FRE CNRS 3744, IRDL, F - 29200 Brest, France- e-mail: kostia.roncin@ensta-bretagne.fr \\ ${ }^{2}$ Beyond the sea, 1010 avenue de l'Europe, 33260 La Teste de Buch, France \\ ${ }^{3}$ CMA CGM, 4 quai d'Arenc, 13235 Marseille cedex 02 France
}

\begin{abstract}
A tool dedicated to assess fuel economy induced by kite propulsion has been developed. To produce reliable results, computations must be performed on a period over several years, for several routes and for several ships. In order to accurately represent the impact of meteorological trends variations on the exploitability of the kite towing concept, a time domain approach of the problem has been used. This tool is based on the weather database provided by the ECMWF ${ }^{1}$. Two sailing strategies can be selected for assessing the performance of the kite system. For a given kite area, the simulation can be run either at constant speed or at constant engine power. A validation has been made, showing that predicted consumption is close from in-situ measurement. It shows an underestimation of $11.9 \%$ of the mean fuel consumption mainly due to auxiliary consumption and added resistance in waves that were not taken into account. To conclude, a case study is performed on a 2200 TEU container ship equipped with an $800 \mathrm{~m}^{2}$ kite on a transatlantic route between Halifax and Le Havre. Round trip simulations, performed over 5 years of navigation, show that the total economy predicted is of around $12 \%$ at a speed of 16 knots and around $6.5 \%$ at a speed of 19 knots.
\end{abstract}

Keywords: wind propulsion, kite, fuel economy, time domain simulation, ship, route, containership

\section{Outil d'évaluation d'économies de carburant pour la propulsion par cerf-volant des navires marchands}

\begin{abstract}
RÉSUMÉ. - Un outil dédié à l'évaluation des économies de carburant faites par cerf-volant a été développé. Pour être fiables les calculs doivent porter sur des périodes longues de plusieurs années, sur différentes routes et différents navires. Afin d'appréhender au mieux les effets de l'alternance des phénomènes météorologiques sur l'opérabilité du système, une approche temporelle a été retenue. Celle-ci se base sur l'utilisation d'une base de données mise à disposition par l'ECMWF'. Les performances du système de propulsion par cerf-volant peuvent être évaluées via deux stratégies de navigation différentes qui sont à vitesse constante ou à puissance constante et ce pour une surface d'aile souhaitée. Une validation a été réalisée et montre que la consommation du navire prédite par le programme est proche de celle mesurée en mer. Elle montre une sous-estimation de $11.9 \%$ sur la consommation moyenne, principalement liée au fait que les consommations auxiliaires et la résistance ajoutée dans les vagues ne sont pas prises en compte. In fine, un cas d'étude est présenté pour un porte-conteneurs de $2200 \mathrm{EVP}$ et une aile de $800 \mathrm{~m}^{2}$ sur une route transatlantique reliant Halifax au Havre. Les résultats montrent sur une période simulée de 5 ans, une économie globale aller-retour d'environ $12 \%$ pour une vitesse de 16 nœuds et d'environ $6.5 \%$ pour une vitesse de 19 nœuds.
\end{abstract}

Mots-clés : propulsion éolienne, cerfs-volants, économies de carburant, simulation temporelle, navire, porte-conteneur

\section{INTRODUCTION}

Kite propulsion, like many other wind propulsion devices, has been considered with interest for reducing greenhouse gases and fuel consumption. In order to demonstrate the efficiency of the system, focussing only on aerodynamic properties is not sufficient. As suggested by Naaijen and Koster [2007], system performances highly depend on the considered maritime route. Thus, kite operating context should be of prime concern. To get the most insight into the kite propulsion efficiency, a dedicated simulation tool based on Leloup et al. [2016] previous work, has been especially tailored at ENSTA Bretagne. This paper presents the leading concepts of the simulation tool, and its validation and results from a case study on a transatlantic route.

1. European Centre for Medium-Range Weather Forecasts

\section{GENERAL PRINCIPLE}

The algorithm developed for this program is based on spatial and temporal discretization of meteorological data encountered by the vessel along its journey. The great circle route between two ports of destination is discretized in a sufficient number of points to get a fair depiction of meteorological events. If required, control points can be added to impose a specific path or avoid obstacles (coastline, breakers, etc.). This is illustrated in Figure 1. Meteorological data associated to each point of the route are from ERA-Interim data base, provided by the ECMWF [Dee et al., 2011]. Thus, simulation can be run for a specified number of trips (round trip), over the desired period of time. The balance of forces acting on the ship is computed for every spatial and temporal update of the meteorological data. This gives an understanding of the kite propulsion behaviour at a trip level, such as the flying time evolution or the flying mode selected. 


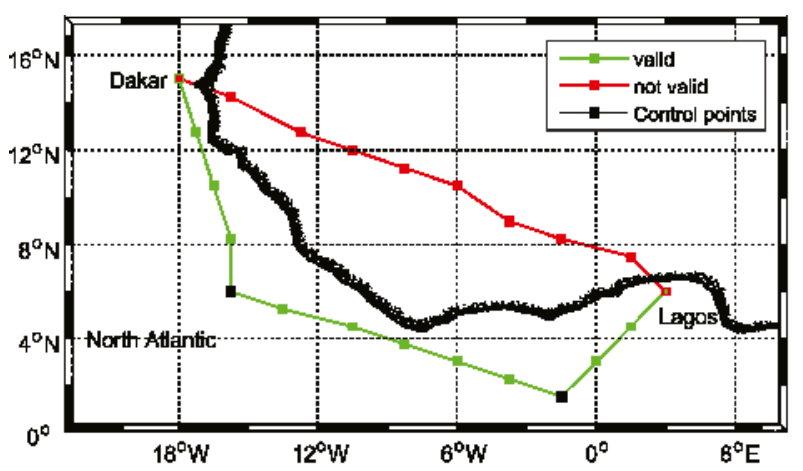

Figure 1: Route discretization

\section{SHIP AND KITE MODELLING}

Only longitudinal forces are considered. Equation (1) gives the balance of the considered forces.

$$
(1-t) T+F_{\text {kite }}=R_{H}+R_{A}
$$

$R_{H}$ is the hydrodynamic resistance of the hull, which can be obtained by towing tank tests or sea trials, CFD analysis or from parametric model. It does not include the added resistance in waves. $R_{A}$ is the aerodynamic resistance, it can be obtained by wind tunnel tests or CFD analysis. In this study, aerodynamics data were provided by Blendermann [1986]. The open water propeller thrust $T$ is computed thanks to associated $K_{T}$ and $K_{Q}$ open water curves. The relation between thrust and torque for a given ship speed can be deduced from these curves. Consequently, engine power and fuel consumption can be computed based on the engine specific fuel consumption.

Kite towing force is denoted by $F_{k i t e}$ and depends on true wind speed, true wind direction and ship speed. This force, originally computed with the kite propulsion optimisation program developed earlier by Leloup et al [2016], is now obtained from a database. This new approach induces a dramatic drop in the computing time by a factor 60 and makes this program suitable for fast computation over numerous trips. A more detailed description of the database technic is given by Podeur et al [2016].

\section{SIMULATION CASE}

Depending on the specified scenario, the ship can experience a variation in speed at constant power or a variation of engine power at constant speed. Both operating solutions are illustrated in Figure 2. Constant speed option is represented by the motion of the equilibrium point from point 1 to point 2. Constant power option is represented by the motion from point 1 to point 3 .

\section{VALIDATION}

Program validation is based on in-situ measurements made on 2200 TEU container ships operating on the Le Havre-Pointe-à-Pitre route. These data, provided by CMA CGM, cover a 3.5 year period of time and give ships daily

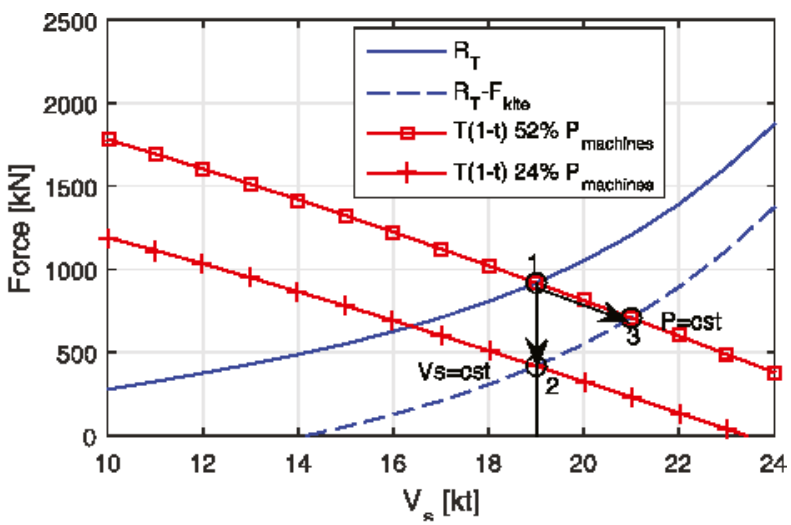

Figure 2: Propulsion - resistance balance

fuel consumption. After modelling this specific type of container ship, a total of 94 round-trip were simulated over the same period of time at a rate of one trip every 15 days and at a constant speed of 19.13 knots. The considered path is the most likely one to be followed and is obtained by performing a $2^{\text {nd }}$ order polynomial fit on dataset of ships positions. Results from this simulation are given in Table 1.

Table 1: Validation results, $\overline{F C} / 24$ denotes the daily mean fuel consumption in tonnes

\begin{tabular}{|c|c|c|c|}
\hline $\begin{array}{c}\text { Container carrier } \\
\text { 2200-EVP }\end{array}$ & Simulation & $\begin{array}{c}\text { Simulation } \\
\text { corrected } \\
\text { (+auxiliary } \\
\text { consumption) }\end{array}$ & Measure \\
\hline$\overline{V_{s}}$ & \multicolumn{3}{|c|}{19.13 knots } \\
\hline $\begin{array}{c}\overline{F C} / 24 \\
\text { (without kite) }\end{array}$ & $56.5 \mathrm{t}$ & $65.7 \mathrm{t}$ & $64.1 \mathrm{t}$ \\
\hline
\end{tabular}

A difference of $11.9 \%$ can be seen between predicted and measured daily fuel consumption. This discrepancy can be justified by solely considering auxiliary fuel consumption, which represent on average $14 \%$ of the total fuel consumption on the measured data. As showed by Minsaas [1983], added resistance in waves could also represent up to $10 \%$ of the total consumption. Based on these corrections and considering the relatively small difference observed between computed and measured data, the model implemented can be considered reliable enough regarding the aims of the present work.

\section{CASE STUDY}

This case study is performed on a transatlantic route between Le Havre and Halifax harbours. The same container ship as for the validation was considered and with the same kite area of $800 \mathrm{~m}^{2}$. Ship and kite characteristics can be found in Podeur et al [2016]. Two sets of simulation were run at 16 and 19 knots, for a total number of 250 trips over a 5 years period of time. Table 2 sums up results from those simulations. 
Table 2: Case study results

W-B denotes west bound leg Le Havre-Halifax, E-B denotes east bound leg Halifax-Le Havre. $\overline{F C}$ denotes the mean fuel consumption in tonnes per trip. $\sigma / \overline{F C}$ denotes the normalised standard deviation of $\overline{F C}$.

\begin{tabular}{|c|c|c|c|c|}
\hline speed & \multicolumn{2}{|c|}{16 knots } & \multicolumn{2}{c|}{19 knots } \\
\hline leg & W-B & E-B & E-B & $33.6 \mathrm{t}$ \\
\hline Mean economy of HFO / Trip & $13.8 \mathrm{t}$ & $42.3 \mathrm{t}$ & $10.2 \mathrm{t}$ & $295 \mathrm{t}$ \\
\hline of HFO/ Trip with kite & $221 \mathrm{t}$ & $188 \mathrm{t}$ & $324 \mathrm{t}$ & $9.56 \%$ \\
\hline$\sigma / \overline{F C}_{\text {kite }}$ & $6.06 \%$ & $14.9 \%$ & $3.92 \%$ & $334 \mathrm{t}$ \\
\hline of HFO/ Trip without kite & $235 \mathrm{t}$ & $230 \mathrm{t}$ & $1.94 \%$ & $1.13 \%$ \\
\hline$\sigma / \overline{F C}$ & $2.02 \%$ & $81.3 \%$ & $50.5 \%$ & $74.5 \%$ \\
\hline \% Mean flying time / Trip & $59.4 \%$ & $18.4 \%$ & $3.05 \%$ & $10.2 \%$ \\
\hline Mean percentage of economy & $5.87 \%$ & \multicolumn{2}{|c|}{$\mathbf{6 . 6 2} \%$} \\
\hline
\end{tabular}

Table 3 : Dispersion evolution of $\overline{F C}$ per trip with kite

\begin{tabular}{|c|c|c|}
\hline $\begin{array}{c}\mathrm{W}-\mathrm{B} / 16 \mathrm{kts} \\
\sigma / \overline{F C}=6.06 \%\end{array}$ & $\rightarrow 0.646 \rightarrow$ & $\begin{array}{c}\mathrm{W}-\mathrm{B} / 19 \mathrm{kts} \\
\sigma / \overline{F C}=3.92 \%\end{array}$ \\
\hline$\downarrow 2.46 \downarrow$ & & $\downarrow 2.44 \downarrow$ \\
\hline $\mathrm{E}-\mathrm{B} / 16 \mathrm{kts}$ & $\rightarrow 0.641 \rightarrow$ & $\mathrm{E}-\mathrm{B} / 19 \mathrm{kts}$ \\
$\sigma / \overline{F C}=14.9 \%$ & & $\sigma / \overline{F C}=9.56 \%$ \\
\hline
\end{tabular}

Fuel economy of $5.87 \%$ and $3.05 \%$ on the Le Havre Halifax leg at 16 and 19 knots are predicted. These figures noticeably increase to $18.4 \%$ and $10.2 \%$ on the Halifax - Le Havre leg. It can be observed that fuel economy depends on both ship speed and considered leg. Reducing speed on both legs increases the fuel economy. Economy also increases when sailing on the east-bound leg compared to west-bound leg. In both cases, this is due to more favourable relative wind angles. Regarding normalised standard deviation $\sigma / \overline{F C}$ of fuel consumption per trip, it can be noticed that kite propulsion introduces a higher dispersion than without kite. As detailed in table 3, ship speed and the considered leg have a significant impact. Increasing the speed from 16 to 19 knots induces a factor of about 0.64 on the normalised standard deviation $\sigma / \overline{F C}$ on both legs. A factor of about 2.45 on $\sigma / \overline{F C}$ also appears between east-bound and west bound legs, at both 16 and 19 knots. Table 3 sums up the multiplication factor between each values of normalized standard deviation regarding the variation of speed or sailing direction. A remarkable symmetry can be observed about multiplication factors.

\section{CONCLUSION}

A fuel economy assessment tool for merchant ship assisted by kite propulsion was presented. This fast tool allows massive computations over a long period of time. The fuel consumption model was compared to in-situ measurements made on a transatlantic route over a 3 year period and gives satisfactory results. A case study was presented for a container carrier of 2200 TEU, sailing between Halifax and Le Havre harbours and equipped with a $800 \mathrm{~m}^{2}$ kite. This study shows that, over a 5 year period, a potential fuel economy of around $12 \%$ and $6.5 \%$ can be reached respectively at 16 and 19 knots on a North Atlantic crossing.

\section{ACKNOWLEDGMENTS}

Authors would like to thanks the French environment and energy management agency (ADEME) for their financial support.

\section{REFERENCES}

Blendermann, W. (1986) - Die Windkräfte am Schiff. Entwerfen von Schiffen und Schiffssicherheit M-6Ship Design and Ship Safety M-6. Schriftenreihe Schiffbau, 467.

Dee, D. P., Uppala, S. M., Simmons, A. J., Berrisford, P., Poli, P., KoBAYASHI, S., ET AL. (2011) - The ERA-Interim reanalysis: configuration and performance of the data assimilation system. Q.J.R. Meteorol. Soc., 137, 553-597.

Leloup, R., Roncin, K., Behrel, M., Bles, G., Leroux, J. B., Jochum, C., Parlier, Y. (2016) - A continuous and analytical modelling for kites as auxiliary propulsion devoted to merchant ships, including fuel saving estimation. Renewable Energy, 86, 483-496.

MinSAAS, K.J. (1983) - Ship Design For Fuel Economy. Norwegian Hydrodynamic Laboratory. Internal report. Trondheim.

NAAiJen P., Koster V. (2007) - Performance of auxiliary wind propulsion for merchant ships using a kite. 2nd International Conference on Marine Research and Transportation. Naples.

Podeur V., Merdrignac D., Behrel M., Roncin K., Fonti C., Jochum C., Parlier Y., Renaud P. (2016) - Simulation de voyage au long cours pour le calcul d'économies de carburant : application à la propulsion par cerf-volant. 15e Journées de l'Hydrodynamique. Brest. 